\section{Learned Treatise}

Nathalie DeFabrique

Cook County Department of Corrections,

Chicago, IL, USA

\section{Synonyms}

Authoritative reference

\section{Definition}

A learned treatise is authoritative text, which is considered evidence that is provided to support claims. Learned treatise is admissible as evidence in court. Learned treatise can be text that an expert witness used that text to reach his conclusions. Under the Federal Rules of Evidence, either party can introduce a learned treatise as evidence.

\section{Cross-References}

- Federal Rules of Evidence

\section{References and Readings}

Greiffenstein, M. F. (2009). Basics of forensic neuropsychology. In J. Morgan \& J. Ricker (Eds.), Textbook of clinical neuropsychology. New York: Taylor \& Francis. Greiffenstein, M. F., \& Cohen, L. (2005). Neuropsychology and the law: Principles of productive attorney neuropsychologist relations. In G. Larrabee (Ed.), Forensic neuropsychology: A scientific approach. New York: Oxford University Press.

Kaufmann, P. M. (2008). Admissibility of neuropsychological evidence in criminal cases: Competency, insanity, culpability, and mitigation. In R. Denney \& J. Sullivan (Eds.), Clinical neuropsychology in the criminal forensic setting. New York: Guilford Press.

Melton, G. B., Petrila, J., Poythress, N. G., \& Slobogin, C. (2007). Psychological evaluations for the courts (3rd ed.). New York: Guilford Press. 